\title{
Design and optimization of novel in situ gel of mercaptopurine for sustained drug delivery
}

\author{
Nagendra R., Roopa S. Pai*, Gurinder Singh \\ Department of Pharmaceutics, Al-Ameen College of Pharmacy, Karnataka, India
}

\begin{abstract}
Mercaptopurine is a purine antagonist, belonging to the class of antimetabolites. Its oral absorption is erratic and variable throughout GIT, with bioavailability of 5-37\% and belongs to Biopharmaceutical Classification System (BCS) class IV. The focus of the present study was to improve solubility of mercaptopurine and to release the drug uniformly throughout the GIT by formulating into a novel in situ gel tablet. By in vitro swelling studies, xanthan gum was selected as the best gelling polymer and the tablets were prepared by direct compression. Sodium chloride was used as a release modifier to improve the release of drug from the tablet. A $3^{2}$ full factorial design was applied to optimize the percentage of xanthan gum and sodium chloride to get desired swelling index and release profile. Tablets were evaluated for weight variation, hardness, friability, disintegration time, drug content, in vitro swelling studies and in vitro dissolution studies. The best optimized formulation showed good swelling index and extended the release up to $12 \mathrm{~h}$, where as conventional tablet released the drug within $45 \mathrm{~min}$. The results indicate that mercaptopurine loaded in situ gel tablet could be effective in sustaining drug release for a prolonged period of time throughout the GIT, which can possibly improve the oral bioavailability.
\end{abstract}

Uniterms: Mercaptopurine/solubility. Mercaptopurine/drug delivery. Xanthan gum/use. Tablets/in situ gel.

Mercaptopurine é um antagonista da purina, pertencente à a classe dos antimetabólitos. A sua absorção oral é errática e variável através do TGI, com biodisponibilidade de 5-37\% e pertence à classe IV, de acordo com o Sistema de Classificação Biofarmacêutica. O foco do presente estudo foi melhorar a solubilidade da mercaptopurina e liberar o fármaco uniformemente através do TGI, por meio da nova formulação de comprimidos que se tornam gel in situ. Por meio de estudos de inchamento, a goma xantana foi selecionada como o o melhor polímero gelificante e os comprimidos foram preparados por compressão direta. O cloreto de sódio também foi usado como agente modificador de liberação para aprimorar a liberação do fármaco do comprimido. Aplicou-se planejamento fatorial $3^{2}$ para otimizar a porcentagem de goma xantana e de cloreto de sódio para se alcançar o índice de inchamento e o perfil de liberação desejáveis. Os comprimidos foram avaliados quanto à variação de peso, dureza, friabilidade, tempo de desintegração, conteúdo de fármaco, estudos in vitro de inchamento e de dissolução. A formulação mais bem otimizada mostrou bom índice de inchamento e liberação prolongada acima de $12 \mathrm{~h}$, em comparação com um comprimido convencional, que libera o fármaco em 45 minutos. Os resultados indicam que a 6-mercaptopurina carregada no comprimido de gelificação in situ poderia ser eficaz para a liberação controlada por período de tempo prolongado através do TGI, o que pode, possivelmente, aprimorar a biodisponibilidade oral.

Unitermos: Mercaptopurina/solubilidade. Mercaptopurina/liberação do fármaco. Goma xantana/uso. Comprimidos/gelificados in situ.

*Correspondence: Roopa S. Pai. Department of Pharmaceutics, Al-Ameen College of Pharmacy, Hosur Road, Near Lalbagh Main gate, Bangalore 560 027, India. E-mail: roopaspai@yahoo.com 


\section{INTRODUCTION}

Mercaptopurine (6-MP) is a highly insoluble purine antagonist and belongs to the class of antimetabolites and is well known for its antitumor activity. It belongs to BCS class IV (poor solubility and poor permeability). The drug is used to treat leukemia, paediatric non-Hodgkin's lymphoma, Polycythemia Vera and Inflammatory Bowel Disease (such as Crohn's disease and ulcerative colitis). The oral absorption of 6-MP is erratic with only $10-50 \%$ of the administered dose reaches the systemic circulation. The limiting factors in the use of 6-MP are its very short half-life in plasma (0.5-1.5 h) and variable bioavailability (about 5-37\%) (Zacchigna et al., 2007).

By formulating into sustained release (SR) dosage form the above potential problems associated with drug can be overcome (Singh et al., 2012). The most commonly used method for fabricating drugs in a SR formulation is by incorporating them into a matrix containing a hydrophilic rate-controlling polymer. Matrix systems are widely used in oral controlled drug delivery because of their simplicity in manufacturing processes, level of reproducibility, stability of the raw materials and dosage form (Gennaro, 2000).

In situ gel forming tablets are a revolution in oral drug delivery. Gel-forming tablets provide a popular and convenient SR dosage form for delivering drugs over an extended time for 8-24 h (Laity et al., 2010). The drug is dispersed within a polymeric matrix, which controls the release rate. On contact with water or body fluids the outer surface of these tablets swell by polymer hydration and chain relaxation, forming a hydrogel coat (Parka et al., 2010; Baumgartner et al., 2005). When a poorly water soluble drug is dispersed throughout such a polymeric matrix, the swelling mechanism of the polymer results in wetting of the drug, due to sufficient contact between the drug and medium and thus enhancing the solubility of the drug (Ishikawa et al., 2000).

Many synthetic, semi synthetic and natural hydrophilic polymers are used in the formulation of in situ gel tablets. The most commonly used are natural hydrophilic polymers because they are compatible and economical to formulate (Sourabh et al., 2008).

Xanthan gum is a natural and biocompatible anionic polyelectrolyte with a semi-rigid chain structure. It is used to produce directly compressed matrices that display a high degree of swelling due to water uptake. Xanthan gum produces strong elastic gel by direct interaction between the polymeric chains which controls the drug release. Compared to hydroxy propyl methyl cellulose, xanthan gum has the potential advantage of drug release with zero order release kinetics (Mikac et al., 2010).
The primary aim of the present study was to investigate whether it is possible to manufacture in situ gelling tablets of mercaptopurine for enhancing its solubility and bioavailability. Further the study was focused to acquire a comprehensive understanding about the influence of formulation parameters that powerfully affect the characteristics of the in situ gelling tablets. The effect of formulation parameters on swelling index and cumulative percentage release (CPR) was studied using $3^{2}$ randomized full factorial design to obtain an optimal formulation.

\section{MATERIAL AND METHODS}

\section{Material}

Mercpatopurine monohydrate was received exgratis by M/S Dabur Pharmaceuticals Ltd, Ghaziabad, India. Xanthan fum, sodium alginate and hydroxypropyl cellulose (HPC) were purchased from M/S SD finechemicals limited (Mumbai, India). Hydroxy propyl methylcellulose (HPMC E15-LV) was provided ex-gratis by Himedia, Mumbai. PEG-6000 was received ex-gratis by M/S Titan Biotech. Sodium chloride was purchased from M/S Reachem Laboratory Chemicals. All other chemicals used were of analytical grade.

\section{Formulation of in situ gel tablet of mercaptopurine}

To select the most suitable polymer preliminary screening studies were carried out by preparing placebo tablets. The placebo tablets were prepared with xanthan gum (Mikac et al., 2010), sodium alginate (Miyazaki et al., 1995), HPMC (Vazquez et al., 1996), HPC and Poly Ethylene Glycol-6000. The formulation of preliminary trial batches P-1 to P-10 are shown in Table I. The tablets were evaluated for hardness, disintegration time, swelling index.

\section{Evaluation of placebo tablets}

The placebo tablets were evaluated for hardness, disintegration time and in-vitro swelling studies.

\section{Hardness}

Tablets require a certain amount of strength or hardness to withstand mechanical shocks due to handling in manufacturing, packing and shipping. For each formulation, the hardness of 6 tablets was determined using the Monsanto hardness tester. The average hardness was calculated and recorded as $\mathrm{kg} / \mathrm{cm}^{2}$. 
TABLE I - Placebo tablets prepared for screening of polymers

\begin{tabular}{|c|c|c|c|c|c|c|c|c|c|c|}
\hline$\overline{\text { Excipients ( \%) }}$ & $\mathbf{P 1}$ & $\mathbf{P 2}$ & $\mathbf{P 3}$ & $\mathbf{P 4}$ & P5 & P6 & P7 & P8 & P9 & P10 \\
\hline & \multicolumn{2}{|c|}{ Xanthan gum } & \multicolumn{2}{|c|}{ Sodium alginate } & \multicolumn{2}{|c|}{ HPMC } & \multicolumn{2}{|c|}{$\mathrm{HPC}$} & \multicolumn{2}{|c|}{ PEG 6000} \\
\hline Polymer & 50 & 75 & 50 & 80 & 30 & 80 & 20 & 40 & 45 & 80 \\
\hline Talc & 5 & 5 & 5 & 5 & 5 & 5 & 5 & 5 & 5 & 5 \\
\hline Mg. Stearate & 1 & 1 & 1 & 1 & 1 & 1 & 1 & 1 & 1 & 1 \\
\hline MCC & \multicolumn{10}{|c|}{ Quantity sufficient to make $150 \mathrm{mg}$ tablet } \\
\hline
\end{tabular}

*The minimum and maximum percentage of each polymer selected in the above formulations was based on the reported literature.

\section{Disintegration time}

Disintegration time of the formulations was determined using Electrolab disintegration test apparatus. Six tablets were placed individually in each tube of disintegration test apparatus and discs were placed on it. Apparatus was operated using $\mathrm{pH} 1.2$ buffer as medium, maintained at $37 \pm 2{ }^{\circ} \mathrm{C}$. The time required for complete disintegration of the tablets was recorded.

In vitro swelling studies

In vitro swelling studies were performed using USP apparatus of basket type at $37 \pm 0.5^{\circ} \mathrm{C}$ and rotational speed of $50 \mathrm{rpm}$. The tablet from each batch was kept in basket placed in dissolution flask and initial dry weight of basket $\left(\mathrm{M}_{\mathrm{o}}\right)$ was recorded. The basket was placed in $900 \mathrm{~mL}$ of $\mathrm{pH} 1.2$ buffer, for first $2 \mathrm{~h}$. After specific time intervals $30 \mathrm{~min}, 60 \mathrm{~min}$ and $120 \mathrm{~min}$ the basket was taken out and weight of basket $\left(\mathrm{M}_{t}\right)$ was recorded after blotting with tissue paper. Again basket was placed in dissolution flask containing $900 \mathrm{~mL}$ of $\mathrm{pH} 7.4$ phosphate buffer and stirring was carried out at $50 \mathrm{rpm}$. The basket was withdrawn at specific time intervals of $1 \mathrm{~h}$ and weighed for next $10 \mathrm{~h}$ (Babu et al., 2002).

From equation [1] the percentage weight gain by the tablet was calculated using the formula (Deshmukh et al., 2009):

$$
\mathrm{SI}=\frac{\left(\mathrm{M}_{\mathrm{t}}-\mathrm{M}_{0}\right)}{\mathrm{M}_{0}} \times 100
$$

where, $\mathrm{SI}=$ Swelling index, $\mathrm{M}_{\mathrm{t}}=$ Weight of tablet at time ' $\mathrm{t}$ ' and $\mathrm{M}_{\mathrm{o}}=$ Weight of tablet at time ' 0 '.

\section{Formulation of in-situ gel tablets of mercaptopurine with xanthan gum}

Mercaptopurine tablets were prepared by mixing the drug with xanthan gum, where talc, and magnesium stearate were used as glidant and lubricant, respectively.
The formulations F-1 to F-3 were prepared to select the most suitable diluent (Table II). Spray dried lactose and MCC either alone or in combination were used as diluents. The powder blends was passed through sieve no 40 and then the tablets were compressed by direct compression method using tablet compression machine (CIP Punching Machineries Pvt. Ltd, Mumbai, India) with $8 \mathrm{~mm}$ round punch. The tablets were evaluated.

TABLE II - Batches prepared for selection of suitable diluent

\begin{tabular}{lccc}
\hline Ingredients (mg/tab) & F1 & F2 & F3 \\
\hline Mercaptopurine & 50 & 50 & 50 \\
Xanthan gum & 75 & 75 & 75 \\
Talc & 7.5 & 7.5 & 7.5 \\
Magnesium stearate & 1.5 & 1.5 & 1.5 \\
Spray dried lactose & - & 8 & 16 \\
MCC & 16 & 8 & - \\
\hline
\end{tabular}

\section{Evaluation of tablets}

The directly compressed tablets from formulation F-1 to F-3 were evaluated for parameters viz., weight variation, hardness, friability, disintegration time, drug content, in-vitro swelling studies and in-vitro drug release studies.

\section{Weight variation test}

The test was performed according to Indian Pharmacopeial norms. Twenty tablets were weighed individually and average weight was calculated. The individual weights were then compared with average weight. The weight variation was calculated as follows:

$$
\mathrm{PD}=\frac{\mathrm{W}_{\mathrm{avg}}-\mathrm{W}_{\text {ind }}}{\mathrm{W}_{\mathrm{avg}}} \times 100
$$

where, $\mathrm{PD}=$ Percentage Deviation Wavg = Average Weight of Tablet Wind = Individual Weight of Tablet. 


\section{Hardness}

The experimental method described above was used to determine the hardness of formulations F-1 to F-3.

\section{Friability}

The friability of 10 tablets was determined according to US Pharmacopeia using Electrolab (EF2) Friabilator. The friabilator was operated at $25 \mathrm{rpm}$ for 4 minutes or run up to 100 revolutions to know the mechanical strength of the tablet while handling, packing and shipping.

\section{Disintegration time}

The experimental method described above was used to determine the disintegration time for formulations F-1 to F-3.

\section{Drug content}

10 tablets were crushed and powdered blend equivalent to $50 \mathrm{mg}$ of mercaptopurine was weighed and dissolved in in $0.1 \mathrm{~N} \mathrm{NaOH}$. From this $10 \mathrm{~mL}$ was pipetted out into a $100 \mathrm{~mL}$ volumetric flask and volume was made up to $100 \mathrm{~mL}$ with $0.1 \mathrm{~N} \mathrm{NaOH}$. Absorbance was measured at $311 \mathrm{~nm}$ using UV spectrophotometer. Drug content was determined from calibration curve. The experiment was carried out in triplicate.

In vitro swelling studies

The experimental method described above was used to determine in-vitro swelling studies for formulations F-1 to F-3.

\section{Optimization of percentage of polymer and release modifier by $3^{2}$ factorial design}

To optimize the percentage of polymer and release modifier $3^{2}$ full factorial design was applied. In this design 2 factors were evaluated, each at 3 levels, and experimental trials were performed at all 9 possible combinations. The percentage of xanthan gum $\left(\mathrm{X}_{1}\right)$ and release modifier
$\left(\mathrm{X}_{2}\right)$ were selected as independent variables. Swelling index and CPR were the dependent variables. Checkpoint batches were also prepared to prove the validity of the evolved mathematical model (Devi et al., 2009; Singh et al., 2012). Further, mercaptopurine tablets were prepared and the formulations were coded as F-4 to F-12. These formulations were prepared by varying percentage of xanthan gum $(50 \%, 40 \%$ and $30 \%)$ along with sodium chloride in $5 \%, 7.5 \%$ and $10 \%$, respectively as release modifier. (Table III). The level and coded variables are shown in Table IV. These tablets were obtained by direct compression method as discussed in previous section.

Step-wise backward linear regression analysis was used to develop polynomial equations for the dependent variables by using PCP Disso 2000 V3 software. The validity of the derived polynomial equations for the dependent variables (swelling index and CPR) was verified by designing and evaluating two check point formulations (C1 and $\mathrm{C} 2$ ) Table IV.

A statistical model incorporating interactive and polynomial terms was utilized to evaluate the (Equation 2).

$Y=b_{0}+b_{1} X_{1}+b_{2} X_{2}+b_{12} X_{1} X_{2}+b_{11} X_{1}^{2}+b_{22} X_{2}^{2}$

where $\mathrm{Y}$ is dependent variable; $X_{1}, X_{2}$ are the levels (concentration) of the 1, 2 factor; $b_{1}, b_{2}, b_{12}, b_{11}, b_{22}$ are the polynomial coefficients; $b_{0}$ is the intercept (which represents the response when the level of all factors is low).

The main effects $\left(X_{1}\right.$ and $\left.X_{2}\right)$ represent average result of changing one factor at a time from its low to high value. The interaction term $\left(X_{1} X_{2}\right)$ shows how the response changes when two factors are simultaneously changed. The polynomial terms $\left(X_{1}^{2}\right.$ and $\left.X_{2}^{2}\right)$ are included to investigate non-linearity.

\section{Evaluation of tablets}

The directly compressed tablets from formulation F-4 to F-12 were evaluated for post-compression parameter like

TABLE III - Batches prepared for optimization of percentage of polymer and release modifier

\begin{tabular}{lccccccccc}
\hline Ingredients* (mg/tab) & F4 & F5 & F6 & F7 & F8 & F9 & F10 & F11 & F12 \\
\hline Mercaptopurine & 33.3 & 33.3 & 33.3 & 33.3 & 33.3 & 33.3 & 33.3 & 33.3 & 33.3 \\
Xanthan gum & 50 & 50 & 50 & 40 & 40 & 40 & 30 & 30 & 30 \\
Sodium chloride & 5 & 7.5 & 10 & 5 & 7.5 & 10 & 5 & 7.5 & 10 \\
Talc & 5 & 5 & 5 & 5 & 5 & 5 & 5 & 5 & 5 \\
Magnesium stearate & 1 & 1 & 1 & 1 & 1 & 1 & 1 & 1 & 1 \\
MCC & 5.6 & 3.16 & 0.66 & 15.6 & 13.1 & 10.6 & 25.6 & 23.1 & 20.6 \\
\hline
\end{tabular}

* Per $150 \mathrm{mg}$ of tablet 
TABLE IV - Factorial design batches of mercaptopurine tablets

\begin{tabular}{lccccccccccc}
\hline Variables & F4 & F5 & F6 & F7 & F8 & F9 & F10 & F11 & F12 & C1 & C2 \\
\hline X1 & -1 & -1 & -1 & 0 & 0 & 0 & +1 & +1 & +1 & -0.5 & +0.5 \\
X2 & -1 & 0 & +1 & -1 & 0 & +1 & -1 & 0 & +1 & -0.5 & +0.5 \\
\hline
\end{tabular}

weight variation, hardness, friability, disintegration time, drug content, in-vitro swelling studies, in-vitro drug release studies. Kinetic modeling for drug release was applied. The experimental methods described above were carried out. Based on the above evaluation, the best formulation F-11 was selected and further evaluated for compatibility studies such as FTIR and DSC analysis. In-Vitro release behavior of this formulation was compared with marketed formulation. Further the effect of tablet shape and compression force on in-vitro release and swelling index of formulation F-11 was evaluated. The formulation was subjected to stability studies as per ICH guidelines.

\section{Weight variation test}

The weight variation test was carried out as per Indian Pharmacopoeial norms.

\section{Friability}

Tablets were tested for friability using Electrolab apparatus (EF2) (Patel et al., 2005) following procedure described in earlier section.

\section{Hardness}

The experimental method described above was used to determine the hardness of formulations F-4 to F-12.

\section{Drug content}

For drug content determination, 6 tablets were randomly selected and crushed. Powdered blend equivalent to $50 \mathrm{mg}$ of mercaptopurine was weighed, extracted with $0.1 \mathrm{~N} \mathrm{NaOH}$ and analyzed by measuring the absorbance at $311 \mathrm{~nm}$ after suitable dilution, using Shimadzu UV-1601 $\mathrm{UV} / \mathrm{Vis}$ double beam spectrophotometer as procedure described above. The experiment was carried out in triplicate.

\section{In vitro swelling studies}

The experimental method described above was used to determine in-vitro swelling index for formulations F-4 to F-12.

\section{In vitro release studies}

In vitro release studies were carried out in Electrolab TDT-06PL Dissolution tester USP apparatus Type I (rotating basket) at a speed of $50 \mathrm{rpm}$ in $900 \mathrm{~mL}$ of dissolution medium. Initially for $2 \mathrm{~h}$, the study was carried out in simulated gastric fluid $\mathrm{pH} 1.2$ and then medium was filtered through Whatmann filter paper. Furthermore, the tablet retained on filter paper was transferred to dissolution flask and the study was continued up to $10 \mathrm{~h}$ in $\mathrm{pH} 7.4$ phosphate buffer. The temperature was retained at $37.0 \pm 0.5^{\circ} \mathrm{C} .5 \mathrm{~mL}$ of samples were withdrawn at predetermined intervals and were analyzed by UV spectrophotometer at 311nm (Model UV-1700, UV-Visible spectrophotometer, Shimadzu, Kyoto, Japan). Based on in vitro release studies formulation F-11 was selected as best formulation to give a SR effect for $12 \mathrm{~h}$.

\section{Comparison of in-vitro release studies of F-11 with marketed formulation}

In vitro dissolution studies were performed for marketed (MKT) formulation of mercaptopurine (conventional tablet) using Electro lab-USP Dissolution test apparatus of paddle type with RPM of 50. Simulated gastric fluid $\mathrm{pH} 1.2$ was the dissolution medium. Temperature of $37 \pm 0.1{ }^{\circ} \mathrm{C}$ was maintained. $5 \mathrm{~mL}$ of sample was withdrawn at 5, 10, 15, 20, 30 and $45 \mathrm{~min}$ and was replaced with $5 \mathrm{ml}$ of $\mathrm{pH} 1.2$ buffer after each withdrawl. $5 \mathrm{~mL}$ withdrawn sample was filtered. $1 \mathrm{~mL}$ of filtrate was diluted to $10 \mathrm{~mL}$ using $0.1 \mathrm{~N} \mathrm{NaOH}$. The dissolution data of formulation F-11 obtained was compared with the data of MKT formulation. Absorbance was measured at $311 \mathrm{~nm}$ using UV spectrophotometer.

\section{Kinetic modeling of drug release}

The dissolution profile of all the batches was fitted to first-order, zero-order, Higuchi matrix, Hixon-Crowell, Korsmeyer and Peppas to ascertain the kinetic modeling of drug release by using PCP Disso Version 2.08 software, and the model with the highest correlation coefficient was considered to be the best model.

\section{Differential scanning calorimetry}

Differential scanning calorimetry (DSC) studies were conducted using DSC Q2000. Sample was weighed (8.00- 
$10.00 \pm 0.5 \mathrm{mg}$ ) and placed in sealed aluminum pans. The coolant was liquid nitrogen. The samples were scanned at $100{ }^{\circ} \mathrm{C} / \mathrm{min}$ from 200 to $350^{\circ} \mathrm{C}$. DSC thermo grams of pure drug, physical mixture and final formulation were taken.

\section{Powder X-ray diffraction}

Powder X-ray diffraction (PXRD) of pure drug, physical mixture and final formulation were recorded using a Philips PW 1729 X-ray diffractometer with monocrotized $\mathrm{Cu}$ Ka radiation, at a speed of $2 \theta \mathrm{min}^{-1}$ from $10^{\circ}-60^{\circ} 2 \theta$ under the voltage and current of $40 \mathrm{Kv}$ and $30 \mathrm{Kv}$.

\section{Effect of tablet shape and compression force on in-vitro release and swelling for formulation F-11}

The optimized formulation was prepared to study the effect of tablet shape and compression force on invitro release and swelling index. The powder blend was compressed on Rimek MINI PRESS-II SF (Karnavati) using oval punch size of $9.4 \times 5.6 \mathrm{~mm}$ under different compression forces at $2000 \mathrm{~kg}\left(2 \mathrm{~kg} / \mathrm{cm}^{2}\right), 3000 \mathrm{~kg}$ $\left(3 \mathrm{~kg} / \mathrm{cm}^{2}\right), 4000 \mathrm{~kg}\left(4 \mathrm{~kg} / \mathrm{cm}^{2}\right)$ and $5000 \mathrm{~kg}\left(5 \mathrm{~kg} / \mathrm{cm}^{2}\right)$.

\section{In vitro swelling studies}

The experimental method described above was used for formulations F-11.

\section{In vitro release studies}

The experimental method described above was used for formulations F-11.

\section{Stability studies}

Stability testing is an integral part of formulation development. Stability study of the optimized matrix tablets was carried out as per ICH guidelines at $40 \pm 2{ }^{\circ} \mathrm{C} / 75 \% \pm 5 \% \mathrm{RH}$. Physical attributes of the tablets, appearance, percentage drug content and dissolution profiles were tested over a period of 3 months.

\section{RESULTS AND DISCUSSION}

\section{Screening of suitable gelling polymer for preparation of in situ gel tablet}

The placebo tablets containing xanthan gum exhibited best hardness, swelling index and disintegration time as shown in Tablet V, whereas tablets containing PEG-6000 showed least hardness, disintegration time and negligible swelling. Thus xanthan gum was selected as the best in-situ gelling polymer for the preparation of 6-mercpatopurine tablets.

\section{Evaluation of mercaptopurine tablets}

The physicochemical properties of the tablets are summarized in Table VI. The formulation F-1 to F-12 indicated good physical strength as they exhibited excellent hardness ranging from $4.23-5.54 \mathrm{~kg} / \mathrm{cm}^{2}$ and also low friability values of $0.099-0.245 \%$ (Limit $-<0.8 \%$ ), weight variation was found to be $<7.5 \%$ and drug content was found to be in range of $99.193-100.60 \%$, which is within Pharmacopoeial limit (85-115\%).

\section{In vitro swelling studies}

Swelling studies were carried out for all formulations F-1 to F-12. The swelling index indicates that the quantity of water which is absorbed by dissolution medium. The changes in weight, characteristic of water uptake and swelling, depend on amount of xanthan gum present in each formulation. The formulations F-1 to F-3 containing $50 \%$ of xanthan gum showed excellent swelling whereas formulations F-4 to F-12 also contains sodium chloride as release modifier showed reduced swelling. As the percentage of xanthan gum decreases and sodium chloride increases, swelling index decreases as shown in Figure 1. The photographs of in situ gel tablets are shown in Figure 2.

\section{In vitro release studies}

In vitro drug release was determined for the formulated tablets and it was compared with marketed

TABLE V - Hardness, disintegration and swelling index for formulation P-1 to P-10

\begin{tabular}{lcccccccccc}
\hline Evaluation parameters & P1 & P2 & P3 & P4 & P5 & P6 & P7 & P8 & P9 & P10 \\
\hline Hardness $\left(\mathrm{kg} / \mathrm{cm}^{2}\right)$ & 4.5 & 5 & 2.5 & 1 & 2 & 1.5 & 2.5 & 3.5 & 1 & 2.5 \\
Disintegration Time (min) & $>120$ & $>120$ & $>120$ & 110 & 70 & 90 & 102 & $>120$ & 9 & 10 \\
Swelling Index (\%) & 906 & 1679 & 97 & 121 & 56 & 68 & 38 & 41 & - & - \\
\hline
\end{tabular}


TABLE VI - Weight variation, hardness, friability and drug content formulation F-1 to F-12

\begin{tabular}{lcccccc}
\hline Evaluation parameters* & $\mathbf{F 1}$ & $\mathbf{F 2}$ & $\mathbf{F 3}$ & $\mathbf{F 4}$ & F5 & F6 \\
\hline Weight variation (\%) & $4.76 \pm 0.075$ & $3.25 \pm 0.081$ & $4.52 \pm 0.045$ & $5.21 \pm 0.052$ & $4.85 \pm 0.081$ & $5.87 \pm 0.085$ \\
Hardness (kg/cm $\left.{ }^{2}\right)$ & $5.03 \pm 0.208$ & $5.54 \pm 0.152$ & $5.33 \pm 0.115$ & $5.16 \pm 0.152$ & $5.54 \pm 0.152$ & $5.38 \pm 0.102$ \\
Friability (\%) & $0.093 \pm 0.022$ & $0.107 \pm 0.263$ & $0.112 \pm 0.112$ & $0.204 \pm 0.074$ & $0.107 \pm 0.263$ & $0.176 \pm 0.075$ \\
Drug content (\%) & $99.08 \pm 0.04$ & $100.5 \pm 0.20$ & $99.86 \pm 0.15$ & $100.03 \pm 0.23$ & $99.62 \pm 0.20$ & $100.60 \pm 0.33$ \\
\hline Evaluation parameters* & $\mathbf{F 7}$ & $\mathbf{F 8}$ & $\mathbf{F 9}$ & $\mathbf{F 1 0}$ & $\mathbf{F 1 1}$ & $\mathbf{F 1 2}$ \\
\hline Weight variation (\%) & $2.48 \pm 0.022$ & $3.67 \pm 0.038$ & $1.52 \pm 0.036$ & $3.56 \pm 0.56$ & $1.06 \pm \mathbf{0 . 5 9}$ & $2.34 \pm \mathbf{0 . 1 3}$ \\
Hardness (kg/cm $\left.{ }^{2}\right)$ & $4.66 \pm 0.126$ & $4.54 \pm 0.321$ & $4.23 \pm 0.235$ & $4.79 \pm 0.097$ & $4.83 \pm \mathbf{0 . 1 1 2}$ & $4.56 \pm 0.145$ \\
Friability (\%) & $0.099 \pm 0.025$ & $0.117 \pm 0.492$ & $0.111 \pm 0.039$ & $0.196 \pm 0.012$ & $0.145 \pm \mathbf{0 . 1 1 2}$ & $0.245 \pm 0.109$ \\
Drug content (\%) & $99.63 \pm 1.78$ & $100.49 \pm 0.34$ & $100.12 \pm 0.98$ & $99.440 \pm 1.19$ & $99.193 \pm \mathbf{0 . 1 9}$ & $100.36 \pm 1.02$ \\
\hline
\end{tabular}

*Average of three determinations

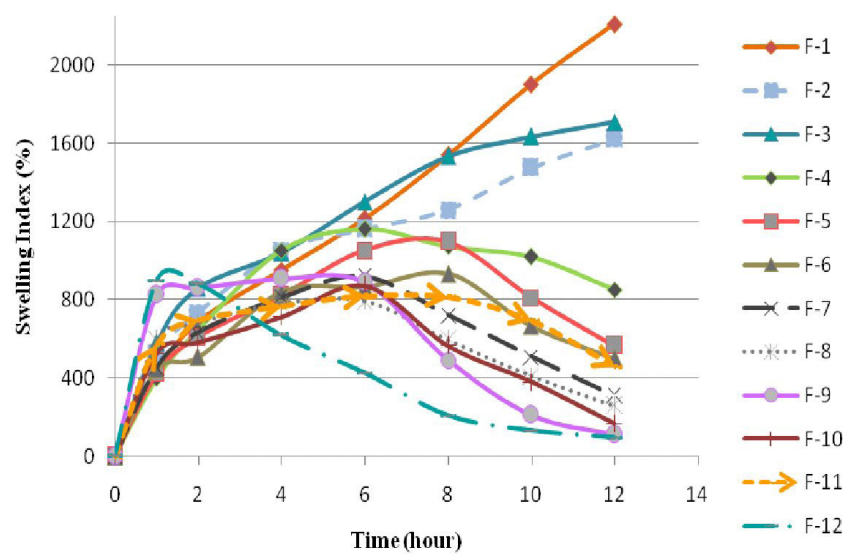

FIGURE 1 - Comparison of in vitro swelling studies for F-1 to F-12.

formulation. Figure 3 shows the effect of diluents (MCC and spray dried lactose) on release rate of mercaptopurine tablets. Formulation F-1 containing MCC alone releases the drug faster when compared to F-2 and F-3, containing spray dried lactose and their combination. The drug release profile of F-1, F-2 and F-3 indicated the need for inclusion of a release modifier in the formulation. Sodium chloride in the concentration range of 5-10\% was chosen as the release modifier. The release data obtained for formulations F-4 to F-12 which were prepared according $3^{2}$ factorial design are given in Table VII and shown in Figure 4.

The formulation F-4 to F-6 containing 50\% xanthan gum with $5 \%, 7.5 \%$ and $10 \%$ of sodium chloride showed percentage drug release of $58.51 \%, 66.13 \%$ and $77.85 \%$ at the end of $12 \mathrm{~h}$. The drug release was found to be less in formulation F-4 to F-6. Further formulations F-7 to F-9 (40\% xanthan gum with 5\%, 7.5\% and $10 \%$ sodium chloride) and F-10 to F-12 (30\% xanthan gum with 5\%, $7.5 \%$ and $10 \%$ sodium chloride) were also prepared. F-7
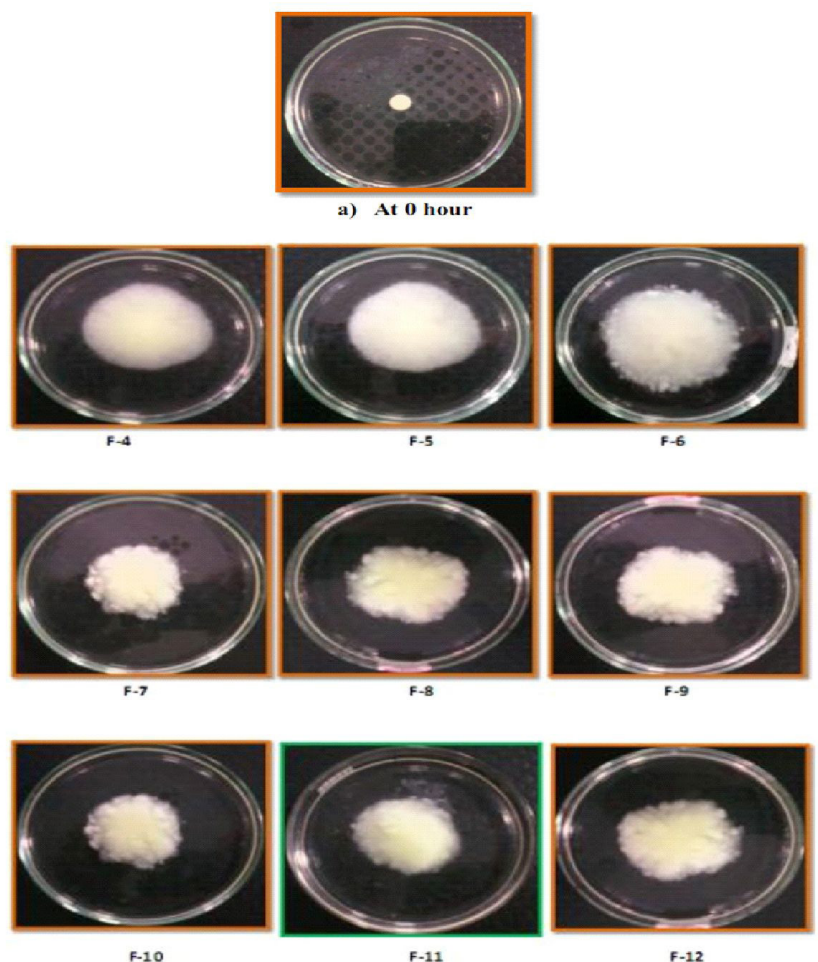

b) After 6 hours

FIGURE 2 - Photographs of in situ gel tablets a) at 0 hour and b) after 6 hours.

and F-8 showed percentage drug release of $75.72 \%$ and $86.13 \%$ at 12 h. But F-9 released $91.3 \%$ of drug within $10 \mathrm{~h}$ due to loss of tablet integrity at higher sodium chloride concentration. F-10 and F-11 showed percentage drug release of $88.2 \%$ and $95.9 \%$ at $12 \mathrm{~h}$. F-12 released $96.22 \%$ of drug at the end of $8 \mathrm{~h}$ because the tablet started eroding after $1 \mathrm{~h}$. As F-11 showed good swelling index and could sustain the release till $12 \mathrm{~h}$, and found to be optimum when compared with the MKT formulation, which released the drug within $45 \mathrm{~min}$ (Figure 4). 
TABLE VII - $3^{2}$ Full factorial design layout

\begin{tabular}{|c|c|c|c|c|}
\hline \multirow{2}{*}{ Batch Code } & \multicolumn{2}{|c|}{ Variable levels in coded forms } & \multirow{2}{*}{ Swelling index } & \multirow{2}{*}{ CPR } \\
\hline & $\mathrm{X}_{1}$ & $\mathbf{X}_{2}$ & & \\
\hline $\mathrm{F} 4$ & +1 & -1 & 1160 & 51.57 \\
\hline F5 & +1 & 0 & 1053 & 48.81 \\
\hline F6 & +1 & +1 & 866.6 & 66.09 \\
\hline F7 & 0 & -1 & 920 & 70.18 \\
\hline F8 & 0 & 0 & 889.3 & 74.59 \\
\hline F9 & 0 & +1 & 540 & 91.3 \\
\hline F10 & -1 & -1 & 872.2 & 75.2 \\
\hline F11 & -1 & 0 & 826.6 & 83.56 \\
\hline F12 & -1 & +1 & 426.6 & 99.8 \\
\hline $\mathrm{C} 1$ & -0.5 & -0.5 & $858.9(853.09)^{*}$ & $74.87(76.16)^{*}$ \\
\hline $\mathrm{C} 2$ & +0.5 & +0.5 & $821.56(825.63)^{*}$ & $73.18(71.32)^{*}$ \\
\hline \multirow{2}{*}{ Coded values } & \multicolumn{4}{|c|}{ Actual values (mg) } \\
\hline & \multicolumn{2}{|c|}{$\mathrm{X}_{1}$ (Xanthan gum) } & \multicolumn{2}{|c|}{$\mathrm{X}_{2}$ (Sodium chloride) } \\
\hline-1 & \multicolumn{2}{|c|}{30} & \multicolumn{2}{|c|}{5} \\
\hline 0 & \multicolumn{2}{|c|}{40} & \multicolumn{2}{|c|}{7.5} \\
\hline+1 & \multicolumn{2}{|c|}{50} & \multicolumn{2}{|c|}{10} \\
\hline-0.5 & \multicolumn{2}{|c|}{35} & \multicolumn{2}{|c|}{6.25} \\
\hline+0.5 & \multicolumn{2}{|c|}{45} & \multicolumn{2}{|c|}{8.75} \\
\hline
\end{tabular}

*Value in parenthesis indicates the predicted values.

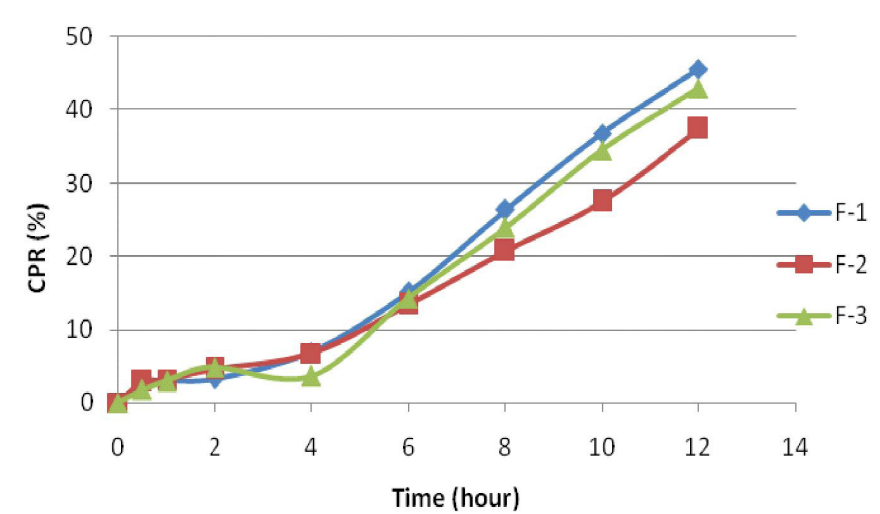

FIGURE 3 - Comparison of in-vitro release studies for F-1 to F-3.

\section{Full factorial design}

The formulations were optimized by applying $3^{2}$ randomized full factorial design. The percentage of xanthan gum $\left(\mathrm{X}_{1}\right)$ and percentage of release modifier $\left(\mathrm{X}_{2}\right)$ were selected as independent variables. Swelling index and CPR were the dependent variables.

From the data of experimental design and parameters (Table VII) for factorial formulations F-4 to F-12, polynomial equations for two dependent variables

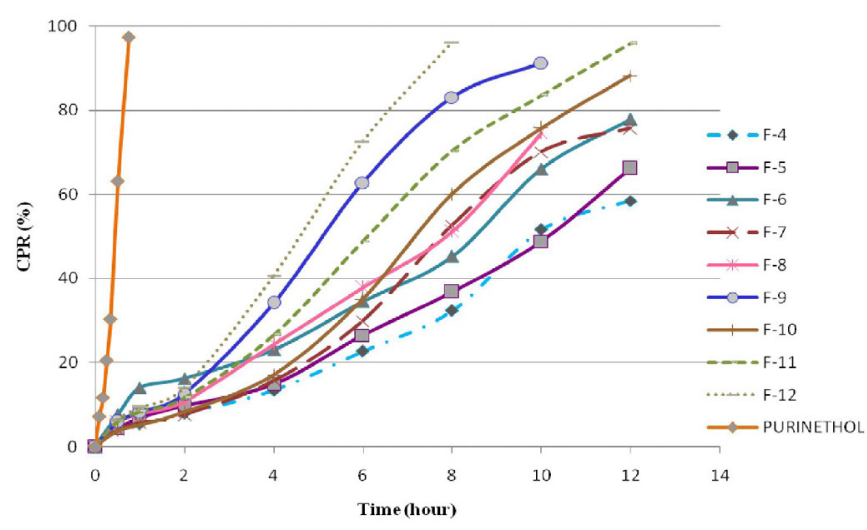

FIGURE 4 - Comparison of in vitro release studies of optimized formulations with MKT formulation.

(swelling index and in vitro release study) were derived using PCP Disso 2000V3 software.

The equation derived for swelling index is:

$$
\mathrm{Y}_{1}=839.36+159.03 \mathrm{X}_{1}-186.50 \mathrm{X}_{2}
$$

The equation derived for $\mathrm{CPR}$ is:

$\mathrm{Y}_{2}=74.835-14.887 \mathrm{X}_{1}+10.04 \mathrm{X}_{2}-2.765 \mathrm{X}_{1} \mathrm{X}_{2}-$

$7.390 \mathrm{X}_{1}^{2}+5.781 \mathrm{X}_{2}^{2}$ 
In equation (3) negative sign for coefficient of $\mathrm{X}_{2}$ indicated that as the concentration of release modifier increased, swelling index decreases and positive sign for coefficient of $X_{1}$ indicates that an increase in polymer concentration increases the swelling index.

In equation (4) negative sign for coefficient of $X_{1}$ indicates that an increase in polymer concentration, $\mathrm{CPR}$ decreases. Positive sign for coefficient of $\mathrm{X}_{2}$ indicates that CPR increases with increase in release modifier concentration. The negative sign for coefficient of $\mathrm{X}_{1} \mathrm{X}_{2}$ indicates that no significant interaction is observed between the 2 factors if they are changed simultaneously.

\section{Response surface plots}

Graphical presentation of the data can help to show the relationship between response and independent variables. Graphs gave information similar to that of the mathematical equations obtained from statistical analysis. The response surface graphs of swelling index and CPR are presented in Figure 5 and Figure 6, respectively.

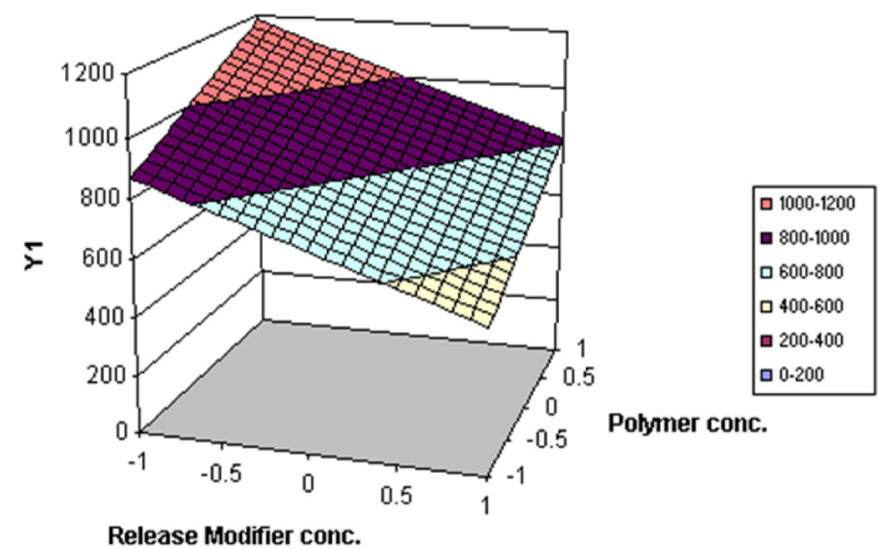

FIGURE 5 - Response surface plot showing effect of factorial variables on swelling index.

The response surface plots illustrated that as percentage of polymer increases, the swelling index increases and CPR decreases but when percentage of release modifier increases, swelling index decreases and CPR increases.

\section{Check point formulation}

Validity of the equations was verified by designing two check point formulations $(\mathrm{C} 1$ and $\mathrm{C} 2)$. The swelling index and CPR predicted from the equations derived and those observed from experimental results are summarized in Table VII. The closeness of predicted and observed values for the swelling index and CPR indicates

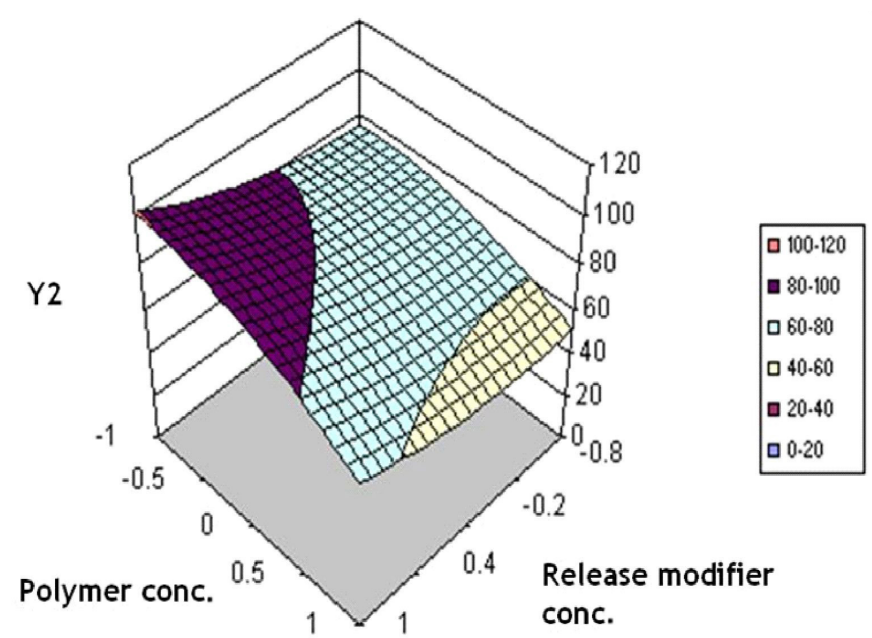

FIGURE 6 - Response surface plot showing effect of factorial variables on CPR.

the validity of derived equations for the dependent variables.

\section{Kinetic modeling of drug release}

The dissolution data of batches F-4 to F-12 was fitted to various release kinetic models. Most of the formulation batches which follows Zero order release. Table VIII lists out the regression parameters obtained after fitting various release kinetic models to the in vitro dissolution data. The release profile of the best batch, F-11, was ranked in the order of Zero order $>$ Korsemeyer-Peppas $>$ Hixson Crowell cube root law $>$ Matrix $>$ First order with slope of 8.013 and $\mathrm{R}^{2}$ value of 0.993 . In Zero order, it is assumed that the release rate is independent of concentration.

\section{Differential scanning calorimetry}

DSC thermograms of pure drug, physical mixture and Final optimized formulation F-11 are shown in Figure 7. The thermogram of mercaptopurine exhibit single endothermic broad peak at $314.4{ }^{\circ} \mathrm{C}$ corresponding to the melting point of mercaptopurine. In case of physical mixture, the drug peak shifted to lower temperature of $305.9^{\circ} \mathrm{C}$ with reduced intensity which may be due to baseline shift and an additional peak at $260^{\circ} \mathrm{C}$ was observed due to presence of xanthan gum and microcrystalline cellulose (Melting point $255^{\circ} \mathrm{C}-265^{\circ} \mathrm{C}$ ). Similar peaks were observed for final optimized formulation F-11 with increased intensity that might have occurred due to punching of tablets. Since there was no much difference in the melting point of the drug in all the thermographs, it was concluded that, the drug is in the same pure state even in the formulation F-11 without interacting with the polymers. 
TABLE VIII - Kinetic modeling of drug release

\begin{tabular}{lccccccc}
\hline \multirow{2}{*}{ Formulation } & \multicolumn{4}{c}{ Drug release kinetics, correlation coefficients $\left(\mathrm{r}^{2}\right)$} & Release \\
\cline { 2 - 6 } & Matrix & Zero order & First order & Hixson Crowell & $\begin{array}{c}\text { Korsemeyer- } \\
\text { Peppas }\end{array}$ & Best fit model \\
\hline F4 & 0.8751 & 0.9745 & 0.9389 & 0.9527 & 0.9710 & 0.8183 & Zero order \\
F5 & 0.8751 & 0.9722 & 0.9284 & 0.9482 & 0.9473 & 0.7693 & Zero order \\
F6 & 0.8765 & 0.9707 & 0.9187 & 0.9414 & 0.9116 & 0.7071 & Zero order \\
F7 & 0.8954 & 0.9892 & 0.9430 & 0.9634 & 0.9773 & 0.8992 & Zero order \\
F8 & 0.9006 & 0.9899 & 0.8430 & 0.9341 & 0.9759 & 0.8584 & Zero order \\
F9 & 0.9064 & 0.9902 & 0.7977 & 0.9032 & 0.9733 & 0.7801 & Zero order \\
F10 & 0.8863 & 0.9841 & 0.9196 & 0.9506 & 0.9560 & 0.8900 & Zero order \\
F11 & 0.9118 & 0.9936 & 0.8566 & 0.9336 & 0.9785 & 0.8283 & Zero order \\
F12 & 0.8927 & 0.9900 & 0.8418 & 0.9215 & 0.9923 & 1.1393 & Korsemeyer- \\
& & & & & & & Peppas \\
\hline
\end{tabular}

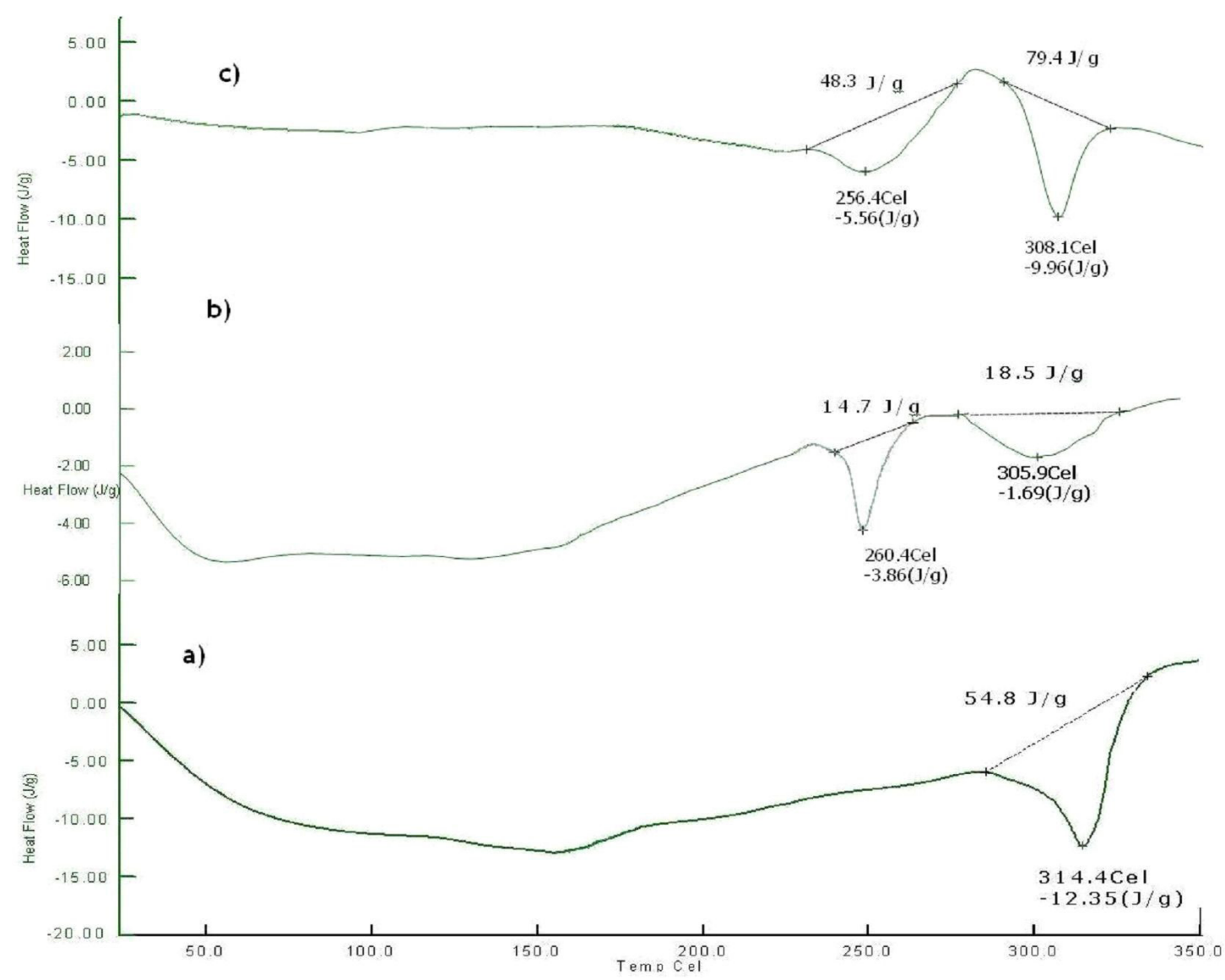

FIGURE 7 - DSC spectras of a) Pure mercaptopurine b) Physical mixture and c) Formulation F-11.

\section{X-ray diffraction studies}

Diffraction spectra of pure mercaptopurine, physical mixture and formulation F-11 is shown in Figure 8. The $\mathrm{X}$-ray pattern of pure mercaptopurine revealed a drug fingerprint with intense and sharp peaks, indicating its crystalline nature as demonstrated by numerous distinct peaks observed at 11.8, 14.6, 16.8, 21.2, 23.6, 25.3, 25.9, $27.6,29.5$ and $30.4(2 \theta)$. The prominent peaks of pure mercaptopurine were clearly seen at the same position 


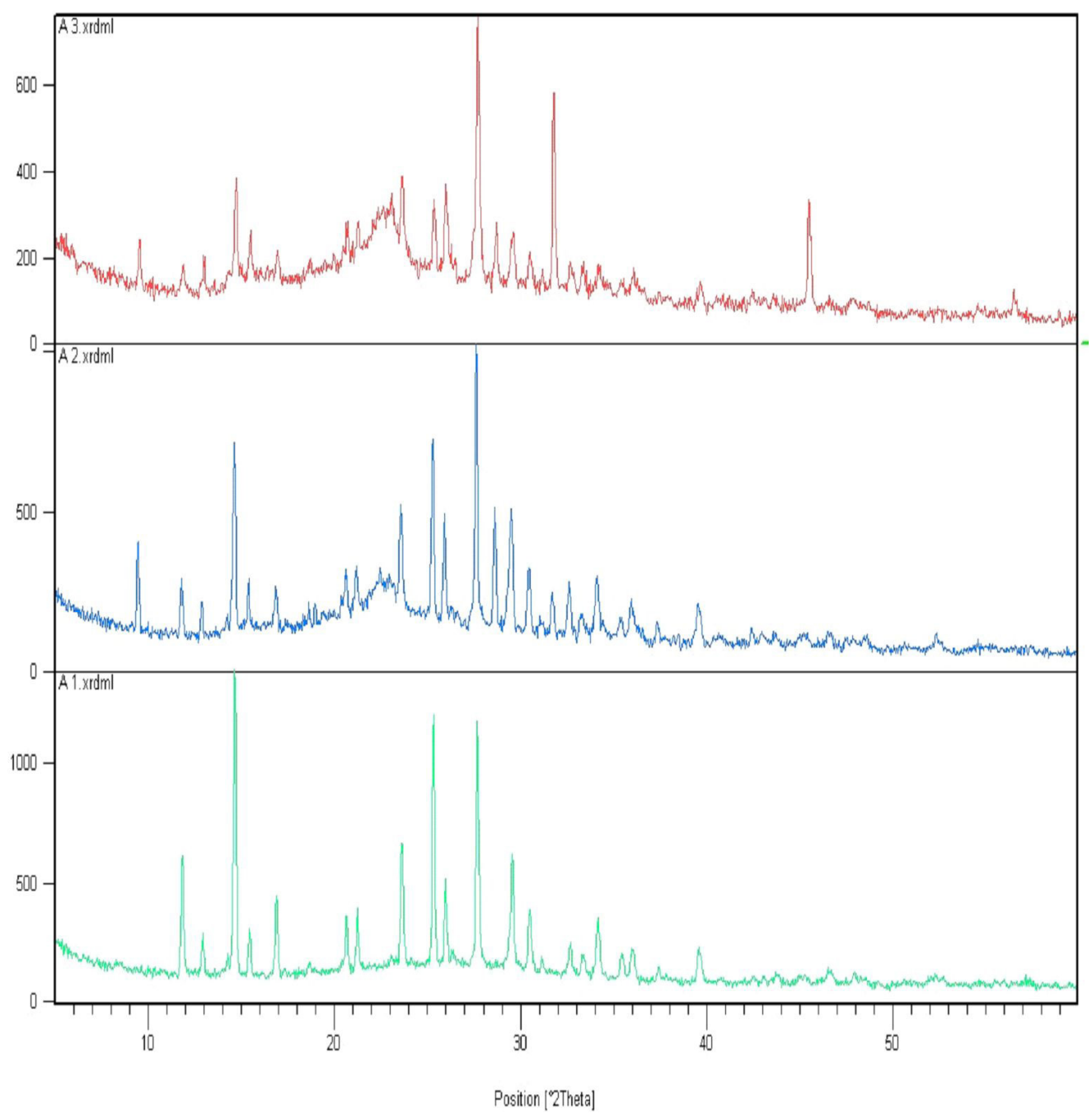

FIGURE 8 - XRD spectras of a) Pure mercaptopurine; b) Physical mixture and c) Formulation F-11.

in the physical mixture and in formulation F-11 with remarkably decreased intensity. No new peaks were observed, suggesting the absence of interaction between the drug and the polymer.

\section{Effect of tablet shape and compression force on in vitro release and swelling}

The change in the tablet shape and compression force alters the in vitro swelling and in vitro dissolution studies. The swelling index of oval shaped tablets of F-11 with different compression forces was found to be maximum at $1 \mathrm{~h}$ in the range of $1073-1280 \%$. As the time progress, tablets started to erode (Figure 9). The in vitro dissolution studies of formulation F-11 with hardness 2 , 3,4 , and $5 \mathrm{~kg} / \mathrm{cm}^{2}$ were found to be 7.0, 7.2, 7.4 and $8.4 \mathrm{~h}$ at $t_{90}$, respectively, whereas round tablet with hardness of $5 \mathrm{~kg} / \mathrm{cm}^{2}$, found to be $10.8 \mathrm{~h}_{\text {at }} \mathrm{t}_{90}$ (Figure 10).

\section{Stability studies}

The accelerated stability studies carried out for a duration of 3 months as per ICH guidelines indicated the best optimized formulation was stable. This was concluded following the evaluation of the formulation for physical appearance, drug content and drug release profile.

\section{CONCLUSION}

The present study was to design and develop novel in situ gel tablet of mercaptopurine for sustained drug delivery. By observing the low solubility problem and its erratic absorption throughout the GIT, an attempt was made to enhance drug absorption by making the drug release throughout the GIT. A systematic study using a $3^{2}$ full-factorial design revealed that by selecting a suitable composition of xanthan gum and sodium chloride, the 


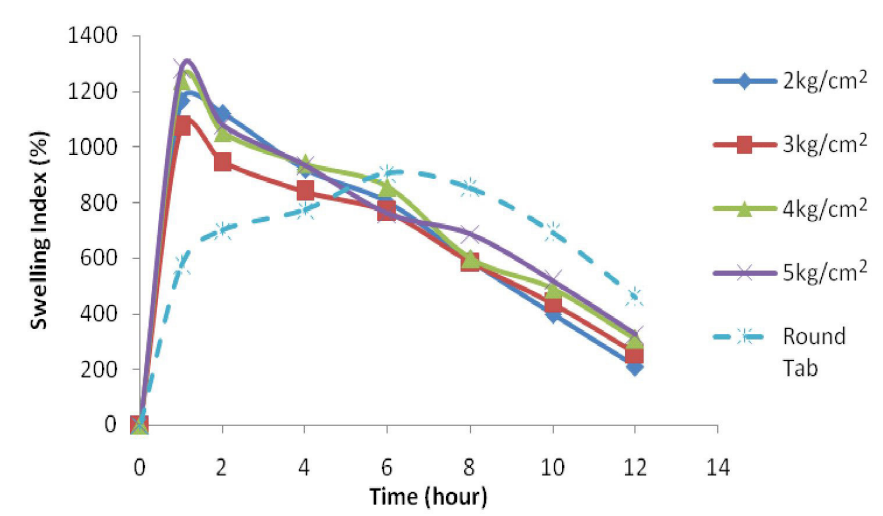

FIGURE 9 - Effect of compression force and tablet shape on swelling index for formulation F-11.

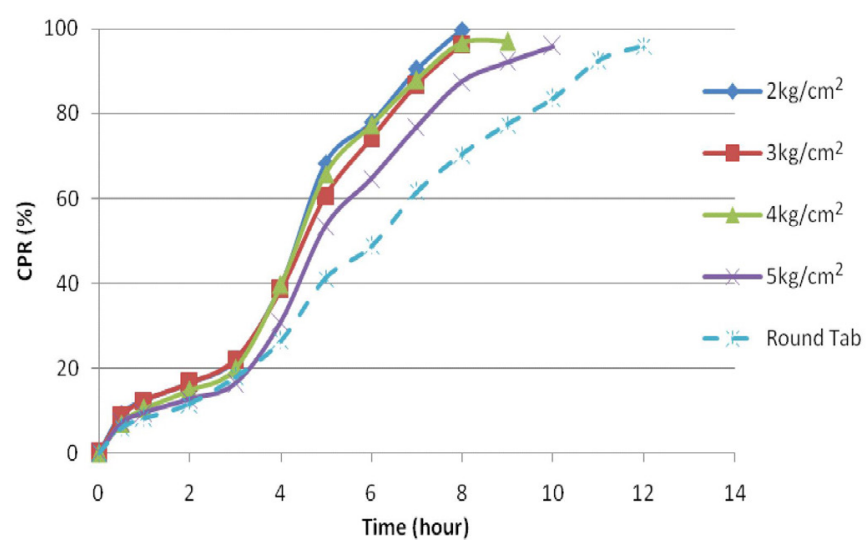

FIGURE 10 - Effect of compression force and tablet shape on in vitro release for formulation $\mathrm{F}-11$.

desired swelling index and release profile can be achieved. The best optimized formulation showed good swelling index and extended the release up to $12 \mathrm{~h}$. Further in vivo investigations may prove the possibility of improvement in the oral bioavailability of the mercaptopurine as an in situ gel tablet.

\section{ACKNOWLEDGMENTS}

The authors are grateful to Prof. B. G. Shivananda, Principal, Al-Ameen College of Pharmacy, Bangalore, for his continuous support. Authors are also grateful to Dabur Pharmaceuticals Ltd., Bangalore, India for providing the gift sample of mercaptopurine monohydrate.

\section{REFERENCES}

BABU, G.V.M.M.; KUMAR, N.R.; SANKAR, K.H.; RAM, B.J.; KUMAR, N.K.; MURTHY, K.V.R. In vivo evaluation of modified gum karaya as a carrier for improving the oral bioavailability of a poorly water-soluble drug, nimodipine. AAPS Pharm.Sci.Tech., v.3, n.2, p.1-9, 2002.
DESHMUKH, V.N.; SINGH, S.P.; SAKARKAR, D.M. Formulation and evaluation of sustained release metoprolol succinate tablet using hydrophilic gums as release modifiers. Int. J. Pharm.Tech. Res., v.1, n.2, p.159-163, 2009.

DEVI, K.V.; BHOSALE, U.V. Formulation and optimization of polymeric nano drug delivery system of acyclovir using $3^{2}$ full factorial design. Int. J. Pharm.Tech. Res, v.1, n.3, p.644-54, 2009.

GENNARO, R.A. Extended release dosage forms. In: Remington: The Science and Practice of Pharmacy. Philadelphia: Lippincott Williams and Wilkins, 2000. 20. ed. v.1, p.660-6633.

INDIAN pharmacopoeia, Controller of publications. New Delhi. 4th edition. 1996;1:532-34.

ISHIKAWA, T.; WATANABE, Y.; TAKAYAMA, K.; ENDO, H.; MATSUMOTO, M. Effect of hydroxypropylmethylcellulose (HPMC) on the release profiles and bioavailability of a poorly water-soluble drug from tablets prepared using macrogol and HPMC. Int. J. Pharm., v.202, n.1-2, p.173$178,2000$.

LAITY, P.R.; CAMERON, R.E. Synchrotron X-ray microtomographic study of tablet swelling. Eur. J. Pharm. Biopharm., v.75, n.2, p.263-276, 2010.

MIKAC, U.; SEPE, A.; KRISTL, J.; BAUMGARTNER, S. A new approach combining different MRI methods to provide detailed view on swelling dynamics of xanthan tablets influencing drug release at different $\mathrm{pH}$ and ionic strength. J. Control. Release., v.145, n.3, p.247-256, 2010.

MIYAZAKI, S.; NAKAYAMA, A.; ODA, M.; TAKADA, M.; ATTWOOD, D. Drug release from oral mucosal adhesive tablets of chitosan and sodium alginate. Int. J. Pharm., v.118, n.2, p.257-263, 1995.

PARK, J.S.; SHIM, J.Y.; NGUYEN, K.V.; PARK, J.S.; SHIN, S.; CHOI, Y.W.; LEE, J.; YOON, J.H.; JEONG, S.H. A pharma-robust design method to investigate the effect of PEG and PEO on matrix tablets. Int. J. Pharm., v.393, n.12, p.79-87, 2010.

PATEL, V.F.; PATEL, N.M. Intragastric floating drug delivery system of cefuroxime axetil: in vitro evaluation. AAPS PharmSciTech., v.7, n.1, p.E17, 2005. 
SINGH, G; PAI, R.S.; DEVI, V.K. Response surface methodology and process optimization of sustained release pellets using Taguchi orthogonal array design and central composite design. J. Adv. Pharm. Technol. Res., v.3, n.1, p.30-40, 2012.

SINGH, G.; PAI, R.S.; DEVI, V.K. Optimization of pellets containing solid dispersion prepared by Extrusion/ Spheronization using Central Composite Design and Desirability function. J. Young Pharmacists., v.4, n.3, p.146-156, 2012.

ZACCHIGNA, M.; CATENI, F.; LUCA, G.D.; DRIOLI, S. A simple method for the preparation of PEG-mercaptopurine for oral administration. Bioorg. Med. Chem. Lett., v.17, n.23, p-6607-6609, 2007.
SOURABH, J.; YADAV, S.K.; PATIL, U.K. Preparation and evaluation of sustained release matrix tablet of Furosemide using Natural Polymers. RJPT, v.1, n.4, p.374-276, 2008.

VAZQUEZ, M.J.; CASALDERREY, M.; DURO, R.; AMOZA, J.L.G.; PACHECO, R.M.; SOUTO, C.; CONCHEIRO, A. Atenolol release from hydrophilic matrix tablets with hydroxypropylmethylcellulose (HPMC) mixtures as gelling agent: effects of the viscosity of the HPMC mixture. Eur. $J$. Pharm. Sci., v.4, n.1, p.39-48, 1996.

Received for publication on $30^{\text {th }}$ March 2013 Accepted for publication on $19^{\text {th }}$ November 2013 
